\title{
Effectiveness of Some Instructional Media for Teaching Organic Chemistry: In the Case of Second Year Chemistry Students of Arba Minch University, Ethiopia
}

\author{
Eyob Mulugeta Kebede \\ College of Natural Sciences, Department of chemistry, Arba Minch University \\ PO box 21, Arba Minch, Ethiopia
}

\begin{abstract}
The research is financed by Asian Development Bank. No. 2006-A171(Sponsoring information) Abstract

Many students have difficulty learning symbolic and molecular representations of chemistry. This action research investigated how students develop an understanding of chemical representations with the aid of a visualizing tool that allowed them to build molecular models and view multiple representations simultaneously. Multiple sources of data were collected with the participation of 30 randomly selected 2nd year Chemistry students and two subject teachers in Arba Minch University (AMU) over 2-weeks period. The results of pre- and post- test showed that students' understanding of chemical representations improved substantially. The analysis of their interviews based on oral questions revealed that ball and stick model helped students to construct models and translate chemical compounds representations. Students who were highly engaged in discussions while using model made referential linkages between visual and conceptual aspects of representations. This in turn may have deepened their understanding of chemical representations and concepts. The findings also suggest that models can serve as a vehicle for students to generate mental images. Finally, students demonstrated their preferences of certain types of representation.
\end{abstract}

Keywords: Teaching aid, Ball and Stick model, instructional media

DOI: $10.7176 / \mathrm{JEP} / 12-22-04$

Publication date:August $31^{\text {st }} 2021$

\subsection{INTRODUCTION}

According to Coombs (1970), Education, consists of two components. He classified these two components into inputs and outputs. According to him, inputs consist of human and material resources and outputs are the goals and outcomes of the educational process. Both the inputs and outputs form a dynamic organic whole and if one wants to investigate and assess the educational system in order to improve its performance, and effects of one component on the other must be examined.

Instructional resources which are educational inputs are of vital importance to the teaching of any subject in the school curriculum. Wales (1975) was of the opinion that the use of instructional resources would make discovered facts glued firmly to the memory of students. Savoury (1958) also added that a well-planned and imaginative use of visual aids in lessons should do much to banish apathy, supplement inadequacy of books as well as arouse students' interest by giving them something practical to see and do, and at the same time helping to train them to think things out themselves. Savoury (1958) suggested a catalogue of useful visual aids that are good for teaching that is, pictures, post cards, diagrams, maps, filmstrips and models.

He said that selection of materials which are related to the basic contents of a course or a lesson helps indepth understanding of such lesson by the students in that they make the lesson attractive to them, thereby arresting their attention and thus, motivating them to learn. He suggested a catalogue of aids which could be used to teach history. He advocated the use of pictures which will help students in grounding their thoughts and feelings. He said that pictures are used as alternatives to real objects where it is impossible to show students the real objects, and they do serve effectively in than imagined activities.

Instructional media must be seen in their relationship to teaching a whole and to the learning process as a whole, until the teacher understands the relationship between instructional media and teaching learning process. They are produced, distributed and used as planned components of educational program. IM helps the process of learning that is motivation, classification and stimulation. It also brings dynamic learning experience more concrete, realistic and clarity to the lesson. Moreover, it provides significant gains in thinking creative reasoning capacity. Scarcity of IMS, according to Coombs (1970), will constrain educational system from responding more fully to new demands. In order to raise the quality of education, its efficiency and reproductivity, better learning materials are needed.

\subsection{Chemistry and Representations}

For decades chemistry educators and researchers have explored how to help students develop a conceptual understanding of chemical representations (Ben-Zvi, Eylon, \& Silberstein, 1986). In this area of research, three 
levels of representations in chemistry have been discussed: macroscopic, microscopic, and symbolic levels (Gabel, 1998). At the macroscopic level, chemical processes are observable, for example, burning candles. At the microscopic level chemical phenomena are explained by the arrangement and motion of molecules, atoms, or subatomic particles. Chemistry at the symbolic level is represented by symbols, numbers, formulas, equations, and structures. Empirical studies Ben-Zvi, Eylon, \& Silberstein, (1987) have shown that understanding microscopic and symbolic representations is especially difficult for students because these representations are invisible and abstract while students' thinking relies heavily on sensory information. In addition, without substantial conceptual knowledge and visual-spatial ability, students are unable to translate one given representation into another (Keig \& Rubba, 1993).

To help students understand chemistry at the three levels, researchers have suggested a variety of instructional approaches, such as adapting teaching strategies based on the conceptual change model (Krajcik, 1991), integrating laboratory activities into class instruction (Johnstone \& Letton, 1990), using concrete models (Copolo \& Hounshell, 1995), and using technologies as learning tools (Barnea \& Dori, 1996). Among these approaches, using concrete models and technologies as learning tools seems promising. For example, viewing dynamic and three-dimensional animations created by technological tools could help students learn to use microscopic and symbolic representations to describe and explain a chemical process (Williamson \& Abraham, 1995). Multiple linked representations provided by multimedia tools allow students to visualize the interactions among molecules and understand the related chemical concepts (Kozma et al., 1996). In addition, manipulating physical models promotes long-term understanding of molecules and atoms (Copolo \& Hounshell, 1995).

Chemical representations refer to various types of formulas, structures, and symbols used to represent chemical processes and conceptual entities (e.g., molecules and atoms). Chemical representations can be viewed as metaphors, models, and theoretical constructs of chemists' interpretation of nature and reality (Hoffman \& Laszlo, 1991). The drawing of molecular structures and the writing of chemical formulas are theory laden and meaning based, created to or construction of theories and experiments. For example, the structural formula of benzene has been changed because of a better understanding of electron resonance. Symbolic and microscopic representations currently used in chemistry evolved from phenomenological analogies of sensory experiences at the macroscopic level (Hoffman \& Laszlo, 1991). They allow chemists to have a common language for their joint inquiry (Nye, 1993) and serve as tools to conduct science investigations and communicate with professional community members (Kozma, et al., 2000). Nowadays chemical representations, such as formulas, symbols, equations, and structures, are widely seen in professional journals and routinely used to describe and explain chemical reactions and phenomena. Being familiar with these representations and their usage in chemistry, therefore, is essential for the acquisition of expertise (Kozma \& Russell, 1997).

\subsection{Students' Learning Difficulties}

Three types of students' difficulties in learning chemical representations have been identified. First, a majority of students at the secondary school level cannot appropriately interpret chemical meanings of representations (Krajcik, 1991). Ben-Zvi et al. (1988) explored the levels of description students generated (e.g., the macroscopic level, the atomic molecular level, the multi-atomic level) when chemical symbols and formulas were used, such as $\mathrm{Cu}(\mathrm{s}), \mathrm{H} 2 \mathrm{O}(\mathrm{l})$, and $\mathrm{Cl} 2$ (g). Although most of them generated some macroscopic descriptions, such as the physical properties of a compound, the atomic-molecular models they used to explain the phenomena were not appropriate. It seems that students rely on their intuitive mental models of atoms and molecules in their explanations or descriptions about these representations and view chemical formulas as representing one particle without the concept of atoms or a collection. Some students, even after receiving substantial chemistry instruction, still view formulas as abbreviations for names rather than a way to represent the composition or structure, while others hold an alternative conception that a formula is an abbreviation for a mixture (Ben-Zvi et al.,1988). In addition to the difficulty of interpreting representations, compared with chemists, students are less capable of providing equivalent representations for a given representation (Kozma \& Russell, 1997). According to Keig and Rubba (1993), a large number of students were unable to make translation among formula, electron configuration, and ball-and-stick model and students' performances on translations were correlated to their understanding of underlying concepts. Keig and Rubba argued that making translation between representations is an information-processing task that requires understanding of the underlying concept. The conceptual knowledge allows students to interpret the information provided by the initial representation and to infer the details in order to construct the target representation (Lesh, et al., 1987).

A third learning difficulty involves the mental transformation between two-dimensional (2-D) and threedimensional (3-D) representations. Many students are not able to form 3-D mental images by viewing 2-D chemical structures and to mentally rotate 3-D images (Selvaratnam, \& Bradley, 1991). In order to successfully create a 3-D image by viewing a 2-D diagram, students are required to decode the visual information provided by depth cues used in the diagram (Shubbar, 1990). These depth cues include the foreshortening of lines, relative sizes of different parts of the structure, representations of angles, and the extent to which different parts of the 
diagram overlap. Tuckey et al. (1991) found that some students cannot correctly identify depth cues, and even if they can, they may not be able to mentally track how depth cues change as a result of rotation (Shubbar, 1990). This makes mentally rotating chemical structures difficult for students.

\subsection{Linking Visual and Conceptual Information of Chemical Representations}

According to the studies discussed above, when students understand representations, they should be able to generate interpretations, make translations, and mentally manipulate these representations (Kozma \& Russell, 1997). These performances of understanding (Perkins, et al., 1995) and representational skills require students to have substantial conceptual knowledge and visual-spatial abilities because chemical representations are conceptual constructs as well as visual displays. Due to the exploratory nature of the studies discussed above, however, none of them characterized the process of how students develop chemistry representational skills in a classroom context. Nor did they discuss possible interaction between the visual and conceptual aspects of chemical representations that in our opinion is the core of chemistry visualization.

\subsection{The Use of Molecular Models and Technological Tools}

In order to ease students' difficulties in learning chemical representations, a variety of strategies have been suggested, one of which is an increased use of physical or computational models. Copolo and Hounshell (1995) compared the learning effects of using 2-D, 3-D physical, and 3-D computational models of molecules on student learning of organic chemical structures. Students who used both physical and computational models scored significantly higher on the retention test compared to other students who used either 2-D or 3-D models. This suggests that the increased visual stimuli provided by both types of models are more effective. Similarly, Gabel and Sherwood (1980) indicated that manipulating physical models had a long-term cumulative effect on students' understanding. Thus, Copolo and Hounshell concluded that both physical and computational models could offer benefits as an effective instructional tool for teaching molecular structures and isomers. However, this experimental study did not provide qualitative data to examine what features of physical and computational models supported students' learning.

\subsection{Visualization Tools and Chemistry Learning}

This study has revealed how students use ball and stick model to assign meanings to novel representations. First, although the bond arrangement features limits students' capability of constructing unstable compounds (e.g., CO and ozone), it encourages students to apply chemical concepts they have learned to be able to choose appropriate bonding. As in Kozma (2000), students' discourses and social interactions were influenced by the resources available to them. Using a visualization tool that illustrates symbolic and microscopic representations encourages students to engage in a discussion of underlying concepts. The action of selecting bond arrangement strengthens and builds students' conceptual linkages among bonding, structures, and molecules. Second, the model rotation feature provided by ball-and-stick model assists students in making visual connections between 2-D and 3-D models. As the empirical studies have shown, a moderate correlation between spatial ability and learning achievement in chemistry (Carter, et al., 1987), manipulating computerized models could improve students' spatial abilities (Barnea \& Dori, 1999). Through externalizing the metal rotation process, eChem might enable students with low spatial abilities to rotate and visualize chemical compound

\subsection{Statement of the Problem}

The use of instructional media (IM) enhances teaching learning process by making the lesson attractive and interesting, adjusting the learning environment and promoting the acceptance of the idea. There are several IM that can be utilized during teaching learning process. The IM that can be employed in teaching Organic Chemistry include ball and stick model, Chemdraw software, charts, periodic table etc. These IM have been found to be very essential for students' independent learning and enhance their achievement. However, these IM are not properly utilized in teaching Organic Chemistry in Chemistry department of AMU. Although the use of IM makes lesson delivery easier and understandable for the students, lecturers in the Chemistry department of AMU always neglect the use of instructional media during teaching learning process. This might be due to instructors work load, shortage of available materials, lack of motivation, and lack of knowledge. Therefore, this action research (AR) will focus on the effective utilization of IM in teaching learning process of Organic Chemistry in order to enhance students' independent learning and maximize their achievement in Organic Chemistry. For this reason, the following basic question will be considered as a vital point of this study.

What will happen to the students understanding of the lesson if the lesson is delivered in the absence of the teaching materials?

Why Chemistry teachers lack motivation, interests to prepare and utilize IM in teaching Organic Chemistry? 


\subsection{Objectives}

\subsubsection{General objective}

The aim of this action research is to see the effectiveness of instructional media for teaching Organic Chemistry for second year Chemistry students.

2.7.2 Specific objectives

To identify the relationship between using instructional media and students understanding during teaching Organic Chemistry

To provide ideas and examples for the use of IM to enhance student learning

To recommend the responsible bodies to encourage and motivate university instructors to develop and utilize different IM to enhance students understanding of the subject matter

\subsection{Significance of the action research}

The significance of this action research is to propose a range of IM that are necessary to make delivery of Organic Chemistry courses easier for the students and maximize student achievement. Teaching Organic Chemistry by using different IM increases motivation of students to learn and easily understand 3 dimensional structural compounds. In addition, this study will provide direction for Organic Chemistry teachers in order to use IMs and also it will initiate teachers in order to solve the problems in the proper use of IMs in Organic Chemistry classes

\section{Methodology of the Action Research}

The action research will be conducted in AMU in the department of Chemistry. The method that used for the collection of data has been interviewing the instructor of organic chemistry found in the department of Chemistry. In addition to this, action will be taken by using IMs for second year chemistry students by dividing the group in to two. One of the groups will be used as a control group and the other used as experimental group. To see the effectiveness of these teaching materials, first both groups taught without using the IM. In the next session, one group taught by using different IMs and the other group taught without these IMs that used as control group. In both cases, the same topic used to evaluate the effectiveness of using these IMs in teaching Organic Chemistry. During the action taking process in the class, different questions prepared and the effect of the IMs will be measured against those questions. In order to minimize the biasness of the action result, groups used as a control will be used as experimental for the second-round action taking process and vice versa.

\section{RESULTS AND DISCUSSION}

\subsection{Data Analysis and Interpretation}

The data analysis and interpretation were obtained through interviews, continuous observation and by assessing the students. The interviews were carried out by two groups of respondents: students and subject teachers. Among 70 students in section A second year Chemistry students, 30 students were randomly selected, and two subject teachers were involved during the interview.

As indicated in table 1, out of 30 selected samples of students, only $10 \%$ of the students responded that the teachers usually used instructional media during their lecture time. $60 \%$ of the students' response indicated the subject teachers never used instructional media.

Table 1: Students response regarding teacher's participation in using instructional media

\begin{tabular}{|c|c|c|c|c|}
\hline \multirow{3}{*}{ No. } & \multirow{3}{*}{ Item } & \multirow{3}{*}{ Alternatives } & \multicolumn{2}{|c|}{ Respondents } \\
\hline & & & \multicolumn{2}{|c|}{ students } \\
\hline & & & Figure & Percent \\
\hline \multirow{4}{*}{1} & \multirow{4}{*}{$\begin{array}{l}\text { Does your Organic } \\
\text { Chemistry teachers } \\
\text { use instructional } \\
\text { media }\end{array}$} & A. usually & 3 & $10 \%$ \\
\hline & & B. some times & 9 & $30 \%$ \\
\hline & & C. never & 18 & $60 \%$ \\
\hline & & Total & 30 & $100 \%$ \\
\hline \multirow{4}{*}{2} & \multirow{4}{*}{$\begin{array}{l}\text { If your answer for } \\
\text { question number } \\
\text { "one" is sometimes, } \\
\text { what is the reason? }\end{array}$} & A. Lack of ability to provide & 4 & $13.3 \%$ \\
\hline & & B. Lack of necessary materials & 5 & $16.7 \%$ \\
\hline & & C. Lack of interest & 21 & $70 \%$ \\
\hline & & Total & 30 & $100 \%$ \\
\hline
\end{tabular}

The delivery of lesson without instructional media reduces students understanding. Table 2 shows that about $66.7 \%$ of students responded that they never understood the subject without the help of instructional media. 
Table 2: Instructional media and its effect in understanding of Organic Chemistry

\begin{tabular}{|c|c|c|c|c|}
\hline \multirow{3}{*}{ No. } & \multirow{3}{*}{ Item } & \multirow{3}{*}{ Alternatives } & \multicolumn{2}{|c|}{ respondents } \\
\hline & & & \multicolumn{2}{|c|}{ students } \\
\hline & & & Figure & Percent \\
\hline \multirow{4}{*}{3} & \multirow{4}{*}{$\begin{array}{l}\text { If your Organic } \\
\text { Chemistry teachers } \\
\text { present the lesson } \\
\text { without the help of } \\
\text { instructional media, } \\
\text { can you understand } \\
\text { the lesson easily? }\end{array}$} & A. Never & 20 & $66.7 \%$ \\
\hline & & B. some times & 7 & $23.3 \%$ \\
\hline & & C. usually & 3 & $10 \%$ \\
\hline & & Total & 30 & $100 \%$ \\
\hline \multirow{4}{*}{4} & \multirow{4}{*}{$\begin{array}{l}\text { If your answer for } \\
\text { question number } \\
\text { "three" is never, } \\
\text { what is the degree of } \\
\text { the effect in your } \\
\text { understanding of the } \\
\text { lesson? }\end{array}$} & A. High & 26 & $86.6 \%$ \\
\hline & & B. Medium & 3 & $10 \%$ \\
\hline & & C. Low & 1 & $3.3 \%$ \\
\hline & & Total & 30 & $100 \%$ \\
\hline \multirow{4}{*}{5} & \multirow{4}{*}{$\begin{array}{l}\text { If your teacher uses } \\
\text { instructional media } \\
\text { properly, what will } \\
\text { happen to your } \\
\text { understanding of the } \\
\text { lesson? }\end{array}$} & A. Very clear & 25 & $83.3 \%$ \\
\hline & & B. Clear & 5 & $16.7 \%$ \\
\hline & & C. With some doubt & 0 & $0 \%$ \\
\hline & & & 30 & $100 \%$ \\
\hline
\end{tabular}

Table 3 illustrates that $50 \%$ of the teacher used instructional media in order to enhance the understanding level of students.

Table 3: Subject teachers' response in using instructional media

\begin{tabular}{|c|c|c|c|c|}
\hline \multirow{3}{*}{ No. } & \multirow{3}{*}{ Item } & \multirow{3}{*}{ Alternatives } & \multicolumn{2}{|c|}{ respondents } \\
\hline & & & \multicolumn{2}{|c|}{ Teachers } \\
\hline & & & Figure & Percent \\
\hline \multirow{3}{*}{6} & \multirow{3}{*}{$\begin{array}{l}\text { Do you use } \\
\text { instructional media } \\
\text { properly? }\end{array}$} & A. Yes & 1 & $50 \%$ \\
\hline & & B. No & 1 & $50 \%$ \\
\hline & & Total & 2 & $100 \%$ \\
\hline \multirow{4}{*}{7} & \multirow{4}{*}{$\begin{array}{l}\text { If your answer for } \\
\text { question number } 6 \\
\text { is yes, how } \\
\text { frequently you use? }\end{array}$} & A. Always & 0 & $0 \quad \%$ \\
\hline & & B. Sometimes & 1 & $50 \%$ \\
\hline & & C. Rarely & 1 & $50 \%$ \\
\hline & & Total & 2 & $100 \%$ \\
\hline
\end{tabular}

The teachers' response regarding the use of instructional media shown in table 4 indicated that they both agreed that the lesson will be very clear if the instructional media are frequently used.

Table 4: Subject teachers' responses regarding the importance of instructional media to improve students' educational understanding

\begin{tabular}{|c|c|c|c|c|}
\hline \multirow{3}{*}{ No. } & \multirow{3}{*}{ Item } & \multirow{3}{*}{ Alternatives } & \multicolumn{2}{|c|}{ Respondents } \\
\hline & & & \multicolumn{2}{|l|}{ Teachers } \\
\hline & & & Figure & Percent \\
\hline \multirow{4}{*}{8} & \multirow{4}{*}{$\begin{array}{l}\text { When you always } \\
\text { use instructional } \\
\text { media in proper } \\
\text { ways, what happen } \\
\text { to your students } \\
\text { understanding? }\end{array}$} & A. Very clear & 2 & $100 \%$ \\
\hline & & B. Clear & 0 & $0 \%$ \\
\hline & & C. With some doubt & 0 & $0 \%$ \\
\hline & & Total & 2 & $100 \%$ \\
\hline \multirow{3}{*}{9} & \multirow{3}{*}{$\begin{array}{l}\text { What are the effects } \\
\text { if instructional media } \\
\text { are not used } \\
\text { properly? }\end{array}$} & $\begin{array}{l}\text { A. More attitudinal } \\
\text { development }\end{array}$ & 0 & $0 \%$ \\
\hline & & $\begin{array}{l}\text { B. Less attitudinal } \\
\text { development }\end{array}$ & 2 & $100 \%$ \\
\hline & & Total & 2 & $100 \%$ \\
\hline
\end{tabular}




\section{Action Plan, Implementation and Evaluation \\ Action plan}

To get solution for the problem, it was planned that what activities has been done, the place where the activities has been conducted, the time when the activities have been carried out and the techniques of performing the activities as shown below.

$>$ Designing the package which consist the implementation of instructional media to improve students understanding structures of organic compounds for second year Chemistry students of AMU.

$>$ Putting the sample students (30 students) from second year Chemistry students section A, 15 students were experimental group and the other 15 students were control groups and vice versa.

$>$ Giving similar tasks or class work for both sample students, on the same topic using instructional media and without the use of instructional media.

$>$ Organizing their performance on the given task and making the final data analysis process.

\section{Action Implementation}

According to the set plan, the following activities were implemented:

$>$ The target students were asked to represent an organic compound in various ways,

> Manipulate molecular models mentally, and

Make translations between various representations.

For example, students were showed a chemical formula, $\mathrm{C}_{5} \mathrm{H}_{10}$, and asked to draw its 2-D structure and represent it in different ways. They were also shown different types of 3-D models (i.e., ball-and-stick, wireframe, and space-Filling models) and asked to indicate whether the models represented the same chemical molecules. Thirty target students were interviewed as pairs. Each interview lasted about $30 \mathrm{~min}$ and was conducted outside the classroom. Several interview strategies were used. First, any information about chemical bonds and related concepts were not mentioned unless the topic was raised by students. Second, any unclear student responses were questioned further. Third, the interviewer remained open to emerging meanings and alternative explanations for the interview questions, although this study was not designed to explore students' alternative conceptions of chemical representations.

\section{Action Plan Evaluation result}

Interview transcripts: The interviews of target students were transcribed, coded, and analyzed to assess target students' understanding of representations. Three types of representation competence are: (a) understanding related to properties and structures, (b) understanding of underlying concepts, and (c) ability to translate various representations. Each type was categorized into three levels. According to students' responses, their conceptual understanding was coded as accurate, partial, and none, and their ability of translation was coded as high, adequate, and low.

\section{Conclusions}

In Harrison and Treagust's study (1996) of students' mental models of atoms and molecules, students had a strong tendency to select the space-filling molecular model as a better representation of a molecule. Similar to their findings, in our study two target students used ball-and-stick models to represent molecular structure of isopropanol and viewed the model as "a more realistic depiction. Although the ball-and-stick models do not demonstrate either appropriate atom sizes or electron clouds surrounding atoms, using them to offer a concrete experience of chemical bonds, atoms, and molecules is necessary for chemistry students. After students develop a basic understanding of bonding, teachers could provide various 3-D models and guide group discussions of how different models convey different information about bonding, atom size, and electrons, as Harrison and Treagust (2000) suggested in their case study. Through discussing or negotiating meanings within a class or within groups, students would be able to realize the limitations and benefits of using different types of representations and to learn to appropriately use different models to solve problems, just as chemists do (Kozma \& Russell, 1997). Students could develop referential connections between visual and conceptual systems that help them make translations among representations. Conceptual knowledge as well as mental images could be cognitive resources for students to demonstrate representational skills.

\section{References}

Barnea, N., \& Dori, Y.J. (1996). Computerized molecular modeling as a tool to improve chemistry teaching. Journal of Chemical Information and Computer Science, 36, 629 - 636.

Barnea, N., \& Dori, Y.J. (1999). High-school chemistry students' performance and gender differences in a computerized molecular modeling learning environment. Journal of Science Education and Technology, $8(4), 257 \pm 271$.

Ben-Zvi, R., Eylon, B., \& Silberstein, J. (1986). Is an atom of copper malleable? Journal of Chemical Education, 
63, $64-66$.

Ben-Zvi, R., Eylon, B., \& Silberstein, J. (1987). Students' visualization of a chemical reaction. Education in Chemistry, July, 117 - 120.

Ben-Zvi, R., Eylon, B., \& Silberstein, J. (1988). Theories, principles and laws. Education in Chemistry, May, 89 $-92$.

Carter, C.S., LaRussa, M.A., \& Bodner, G.M. (1987). A study of two measures of spatial ability as predictors of success in different levels of general chemistry. Journal of Research in Science Education, 24(7), $645 \pm 657$.

Coombs, P.H. (1970). The World Educational Crisis: A system Analysis. New York. Oxford University Press.

Copolo, C.F., \& Hounshell, P.B. (1995). Using three-dimensional models to teach molecular structures in high school chemistry. Journal of Science Education and Technology, 4(4), 295 - 305.

Gabel, D. (1998). The complexity of chemistry and implications for teaching. In B.J. Fraser \& K.G. Tobin (Eds.), International handbook of science education (pp. 233- 248). Boston, MA: Kluwer Academic Publishers.

Harrison, A., \& Treagust, D. (1996). Secondary students' mental models of atoms and molecules: Implications for teaching chemistry. Science Education, 80(5), 509 - 534.

Harrison, A.G., \& Treagust, D.F. (2000). Learning about atoms, molecules, and chemical bonds: A case study of multiple-model use in grade 11 chemistry. Science Education, 84, 352 -381.

Hoffmann, R., \& Laszlo, R. (1991). Representation in chemistry. Angewandte Chemie, 30, 1- 16.

Johnstone, A.H., \& Letton, K.M. (1990). Investigating undergraduate lab work. Education in Chemistry, 28,81 83.

Keig, P.F., \& Rubba, P.A. (1993). Translation of representations of the structure of matter and its relationship to reasoning, gender, spatial reasoning, and specific prior knowledge. Journal of Research in Science Teaching, 30(8), 883- 903.

Kozma, R.B. (2000). Students collaborating with computer models and physical experiments. In C. Hoadley (Ed.), Computer support for collaborative learning (pp. 314- 322). Mahwah, NJ: Erlbaum Associates.

Kozma, R.B., \& Russell, J. (1997). Multimedia and understanding: Expert and novice responses to different representations of chemical phenomena. Journal of Research in Science Teaching, 34, 949 -968.

Kozma, R.B., Chin, E., Russell, J., \& Marx, N. (2000). The roles of representations and tools in the chemistry laboratory and their implications for chemistry instruction. Journal of the Learning Sciences, 9(2), 105- 143.

Kozma, R.B., Russell, J., Jones, T., Marx, N., \& Davis, J. (1996). The use of multiple, linked representations to facilitate science understanding. In R.G.S. Vosniadou, E. DeCorte, \& H. Mandel (Eds.), International perspective on the psychological foundations of technology-based learning environments pp. $41-60$.

Krajcik, J.S. (1991). Developing students' understanding of chemical concepts. In S.M. Glynn, R.H. Yeany, \& B.K. Britton (Eds.),. The psychology of learning science: International perspective on the psychological foundations of technology-based learning environments (pp. 117- 145). Hillsdale, NJ: Erlbaum.

Lesh, R., Post, T., \& Behr, M. (1987). Representations and translation among representations in mathematics learning and problem solving. In C. Janvier (Ed.), Problems of representation in the teaching and learning of mathematics (pp. 33- 40). Hillsdale, NJ: Lawrence Erlbaum Associates.

Nye, M.J. (1993). From chemical philosophy to theoretical chemistry. Berkeley, CA: University of California Press.

Perkins, D.N., Crismond, D., Simmons, R., \& Unger, C. (1995). Inside understanding. In J.L.S.D.N. Perkins, M.M. West, \& M.S. Wiske (Eds.), Software goes to school: Teaching for understanding with new technologies (pp. 70 -91). New York: Oxford University Press.

Salomon, G. (1979). Interaction of media, cognition and learning. San Diego, CA: Jossey Bass.

Savoury, N. J. (1958). "Visual aids in teaching History". West African Journal of Education. Vol. 2. No. 1 pp. 5 -9 .

Shubbar, K.E. (1990). Learning the visualization of rotations in diagrams of three dimensional structures. Research in Science and Technological Education, 8(2), $145 \pm 154$.

Tuckey, H., Selvaratnam, M., \& Bradley, J. (1991). Identification and rectification of student difficulties concerning three-dimensional structures, rotation, and refection. Journal of Chemical Education, 68(6), 460464.

Wales, J. (1966). "The Place of Teaching aids in Nigerian Education", West African Journal of Education, Vol. 3 No. 2.

Williamson, V.M., \& Abraham, M.R. (1995). Then effects of computer animation on the particulate mental models of college chemistry students. Journal of Research in Science Teaching, 32, 521- 534. 